\title{
Economic Activity Weakens
}

G ROWTH in total spending, which moderated in the last half of 1966 , slowed further in the early part of this year. The weakness in total demand has centered in the private sector of the economy, while Government expenditures, especially for defense, have tended to bolster total demand.

With a smaller rate of expansion in demand fot goods and services, the demand for credit has also lessened. As a result interest rates have declined, and other credit terms have been relaxed. With lower interest rates on market instruments, banks and other financial institutions have been able to attract a larger portion of the community's savings to improve their liquidity and to grant more loans.

Government stabilization actions have been mixed. Fiscal policies have been expansionary in the last year and are expected to continue to be stimulative in the next few months. Monetary developments, which were tight last summer and early fall, may have been less restrictive since November. The nation's money stock increased from last November to February after declining in the previous six months.

\section{Interest Rates, Monetary Policy, and Reintermediation}

Interest rates declined after reaching a peak last September; at first the dechne was moderate, but from November to late January rates fell abruptly.

SUBSCRIPTIONS TO THIS BANK'S REVIEW are available to the public without charge, including bulk mailings to banks, business organizations, educational institutions, and otbers. For information write: Research Department, Federal Reserve Bank of St. Louis, P. O. Box 442, St. Louts, Missouri 63166.
In February most rates rose, offsetting a part of the previous decline, but in early March rates again drifted lower.

The three-month Treasury bill yield fell from about 5.50 per cent in miaseptember to 4.50 per cent in early February and was 4.40 per cent in early March. The 4- to 6-month commercial paper rate decreased from 6.00 per cent in October to 5.38 per cent in early February and remaned at that level through early March. Yields on long-term market instruments also declined substantially. From mid-September to early February the market rate on highest grade corporate bonds decreased from 5.50 per cent to 5.00 per cent, but in early March corporate Aa bonds were yielding 5.10 per cent.

Lower interest rates since last fall have been in large meastre a response to slackened credit demands. One reflection of weakened credit demand was the decline in the prime rate, the interest rate charged by banks for loans to their nost credit-worthy customers. From August 16 to about January 30 the prime rate was 6 per cent, after rising from 5 per cent in early December 1965. Beginning in late January of this year most money market banks revised the prime rate downward to $5 \mathrm{~A}$ per cent.

The lower market rates relative to the legal maximum of 5\% per cent on large CD's (those of $\$ 100,000$ and over) at commercial banks have made these deposits more attractive to investors and have contributed to the marked revival of this market. From late December to early March the outstanding volume of CD's at major commercial banks more than recovered the $\$ 3$ billion decline suffered from late August to mid-December.

Savings and consumer-type time deposits of commercial banks have continued to rise rapidly. From December to February time deposits other than large CD's at major banks increased by about $\$ 2$ billion or at an annual rate of 15 per cent. In the year ending last December these deposits rose 7 per cent.

The renewed growth of total time deposits has tended to ease the reserve position of commercial banks and to improve bank liquidity positions. These 


\section{Yields on Selected Securities}

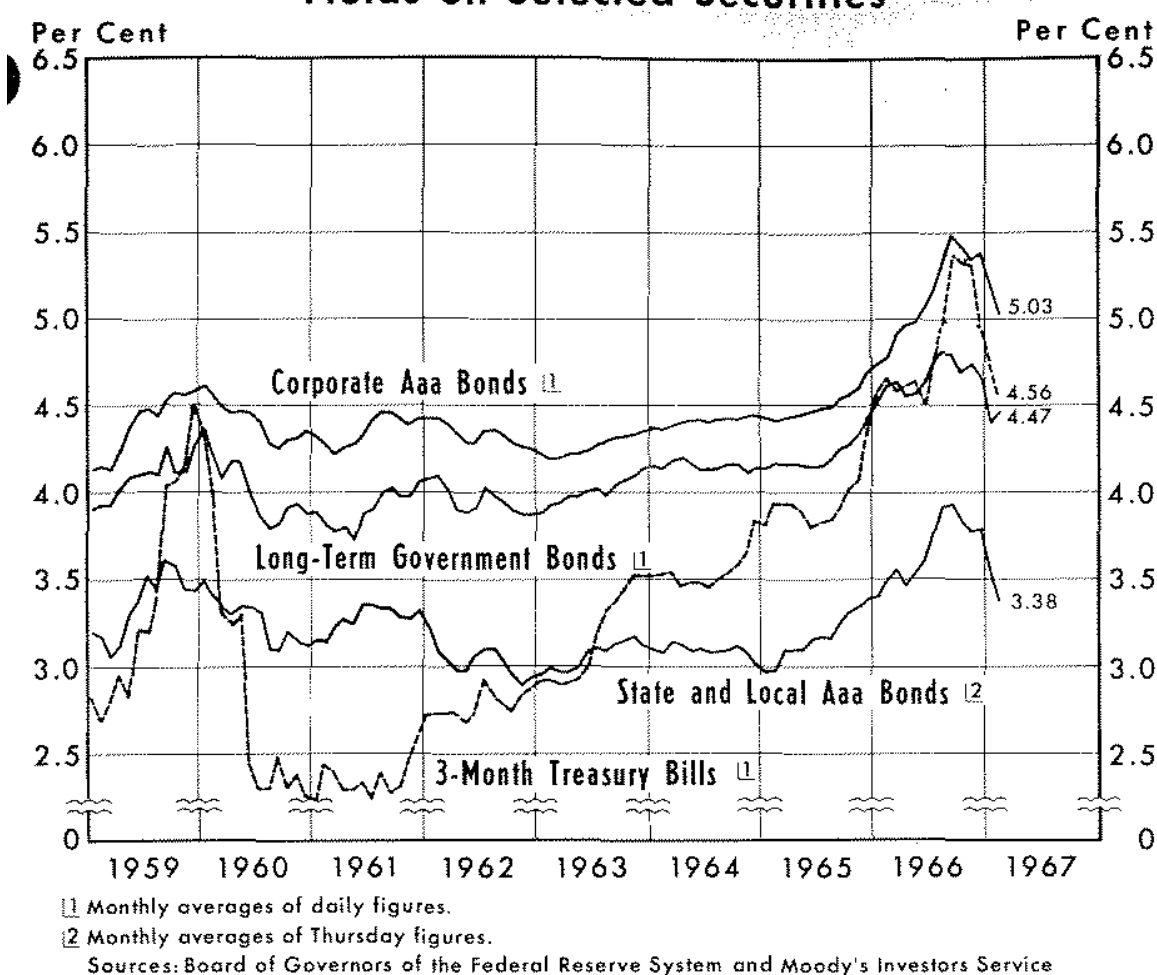

a decline at a 2.6 per cent rate in the previous six months, after adjustments for reserve requirement changes. Most of the reserves have been used to support the renewed bank intermediation. Reserves available for private demand deposits have risen at a 2 per cent rate since November and have changed little since mid-December. Bank reserves are influenced by $\mathrm{Fed}$ 5 eral Reserve action and are important because they set an upper limit on bank deposits (the major part of the money stock).

From November to February total commercial bank credit (loans and investments) increased at an annual rate of 10 per cent compared with a 3.7 per cent rate from May to November. The composition of the growth in bank credit has changed since November as compared with the earlier period. Loans increased at an annual rate of 7 per cent from November to February after rising at an 8 per cent rate from May to November. Bank holdings of U.S. Government securities increased at a 14 per cent annual rate during the period from No vember to February compared with a decrease at a 10 per cent rate from May to November. After a period when banks were drawing down secondary reserves in an attempt to meet a vigorous loan demand, they have more recently been building up liquidity positions.

The nation's money supply (demand deposits and currency) rose from November to February. This apparent recent growth may in some measure be the result of peculiarities of the February figures. From May to November money declined. In the year ending in May, the money supply increased 6 per cent after going up at about a 3 per cent average annual rate from June 1960 to May 1965. Demand deposits rose moderately from November to February, while currency outside banks increased rapidly. The lack of monetary growth last summer and fall probably had a restrictive impact upon economic expansion. When individuals and businesses have less money than they desire to hold, current expenditures are reduced relative to receipts in order to build up cash balances.

On February 28 the Board of Governors of the Federal Reserve System announced a reduction (from 4 per cent to 3 per cent) on reserve requirements
Most monetary indicators have recently been less restrictive than they were last summer and fall. From November to February total member bank reserves rose at about a 13 per cent annual rate compared with 
against savings deposits and the first $\$ 5$ million of other time deposits at member banks. (Each member bank is still required to hold reserves of 6 per cent against its time deposits in excess of $\$ 5$ million.) The requirement on those time deposits affected was scheduled to become $3 \%$ per cent on March 2 and 3 per cent on March 16. An initial effect of the change was to free an estimated $\$ 850$ million of reserves, permitting further expansion in deposits.

\section{Fiscal Conditions}

The Federal Government, according to conventional measures, is providing a substantial stimulus to the economy in the first half of 1967. The national income accounts budget is scheduled to move from a $\$ 2.6$ billion deficit (i.e., expenditures greater than receipts) in the last half of calendar 1966 to about a $\$ 5$ billion deficit rate in the first half of 1967. This budget adjusted for cyclical movements in economic activity (the so-called high-employment budget) is the most expansionary budget in more than a decade. By comparison it averaged about an $\$ 8$ billion surplus from 1961 to 1965.

\section{Sales, Inventories, and Production}

Total spending (GNP in current dollars) increased at an annual rate of 7 per cent in the last three quar-

1 Annual Report of the Council of Economic Advisers, January 1967. For an evaluation of planned fiscal policy see, "The Federal Budget and Economic Stabilization," in the February 1967 issue of this Review. Also, see Federal Budget Trends, a quarterly release of this Bank.

High-Employment Budget (t)Surplus; (-) Deflicit

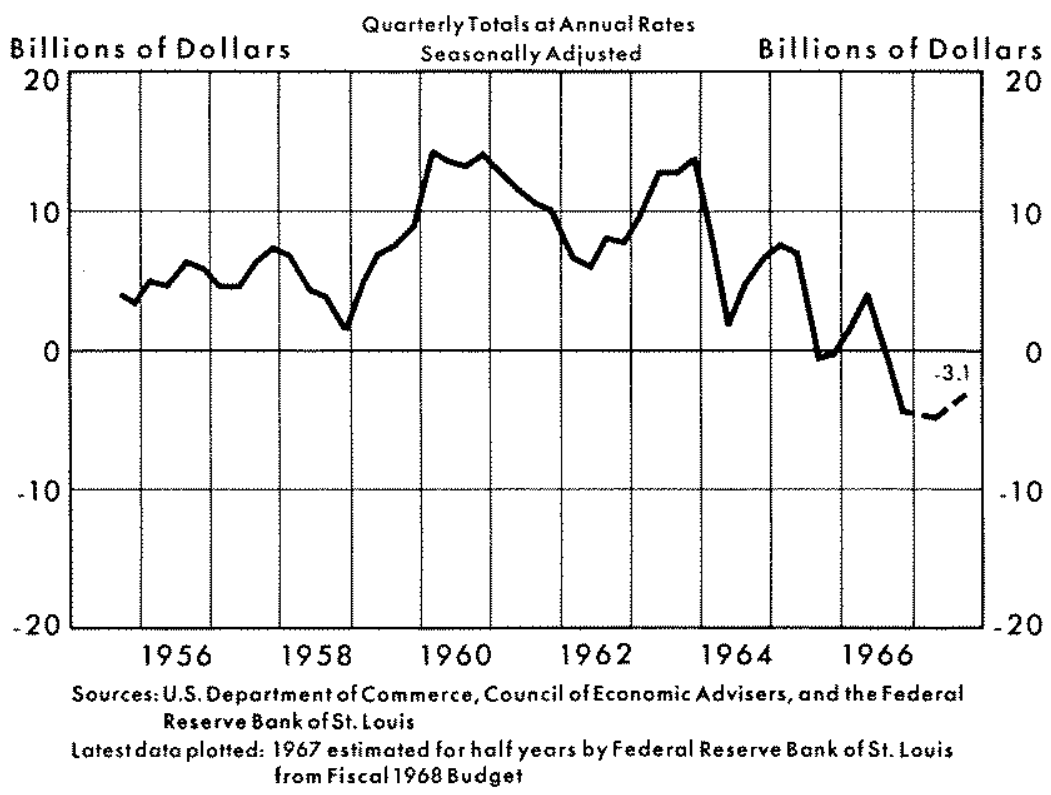

ters of 1966 compared with a 10 per cent rate in the previous five quarters. Although a 7 per cent rate is large relative to growth of productive capacity, weaknesses in key areas of private demand developed in the last half of 1966 which have continued into the early part of this year. These weaknesses have stemmed from a reduced rate of spending by the private sector, while Federal Government expenditures have continued to increase.

Retail sales declined at an annual rate of 4.5 per cent from September to January after rising at a 5 per cent rate in the preceding 10 months. The recent decline consisted primarily of a reduction in sales of automobiles and other durable goods. The smaller spending on appliances and autos may be partially a reaction to the decline in new house purchases as well as a reflection of the rapid pace of auto purchases in the past several years. Consumers may also be attempting to build up their liquidity by spending a smaller share of their incomes. Such cutbacks usually occur in durable goods since existing stocks continue to be usable.

Although business spending has remained large, there are indications that it also has been one aspect of the weakness in aggregate demand. The large business outlays in late 1966 were accounted for in considerable part by an acceleration of inventory accumulation. Business inventory holdings increased at a $\$ 16.4$ billion annual rate in the last quarter of 1966 compared with accumulation at a $\$ 10.4$ billion annual rate in the first three quarters of 1966 and $\$ 9.1$ billion in 1965.

The high rate of inventory accumulation is unsustainable, which suggests that a substantial amount of this accumulation has been involuntary. If this is the case, firms experiencing large inventory accumulation may attempt to bring them into line by reducing the rate of output and purchase of production goods. Such adjustments tend to reduce sales, income, and employment.

During the initial periods of cyclical upswings in business activity, inventories are usually drawn down relative to sales as sales increase at a more rapid pace than production. Inventories frequently reach undesirably low levels relative to sales during the early phases of a business expansion. Consequently, businesses attempt to build up their inventory stock so as to regain a desired relation to sales, but, with sales also rising, the inventory-sales ratio

Page 4 


\section{Changes in Business Inventories}

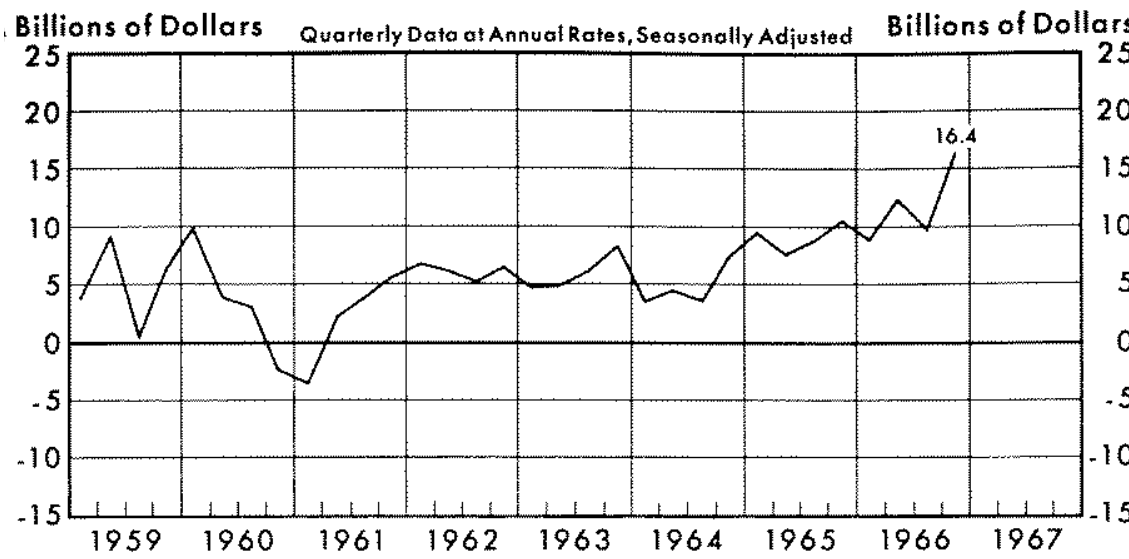

Soufce: U.S. Depoftment of Commerce

tatest data platted: 4 th quarter preliminary

usually remains low during most of the expansionary phase of the cycle. Attempts to build inventories tend to maintain or accelerate income and employment.

In the latter phases of an upswing, when growth in sales slows, inventories usually rise markedly relative to sales. Businesses then attempt to reduce the rate of inventory accumulation by limiting their purchases. These actions, in turn, tend to lower consumer and business incomes, which tend to "feed back," causing a further weakening in sales. Consequently, an attempt to trim inventories to achieve a desired inventory-sales ratio is partially self-defeating.
From 1961 to mid-1966 the inventory-sales ratio declined steadily from 1.54 to 1.48 , with the only interruption occurring in 1962. This ratio increased in late 1966 to 1.54 . Such a marked rise may be a signal that businesses will begin to add to inventories less rapidly. The effect of undesired inventory levels is already taking place 0 according to some indicators. Unfilled orders for durable goods have declined slightly since September after rising steadily in the previous year. Recently, there have been production cutbacks in automobiles and some appliance industries because of a slowdown in sales and rising inventories of dealers.

Growth in production has recently been at a decidedly slower rate than during most recent years. Industrial production declined at a 2.5 per cent annual rate from October to January compared with a 5 per cent rate of increase from June to October and a 9 per cent gain in the previous year. The current slowdown may reflect in part adjustments associated with the reallocation of resources from civilian to military goods production during a period of near full employment. It may also reflect a weakening of consumer and business demand which may now be

Inventories Compared With Monthly Sales* Manufocturing and Trade

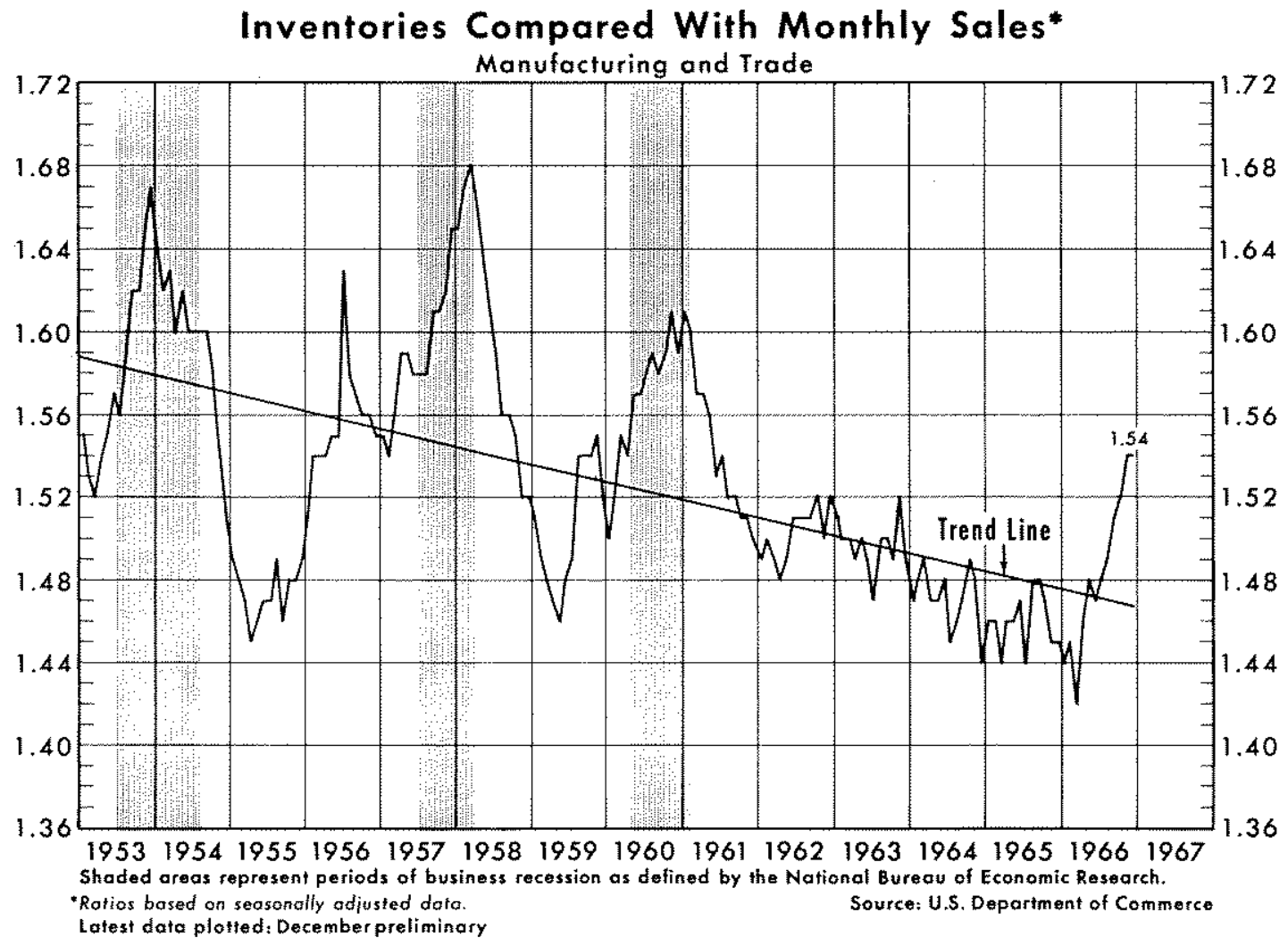




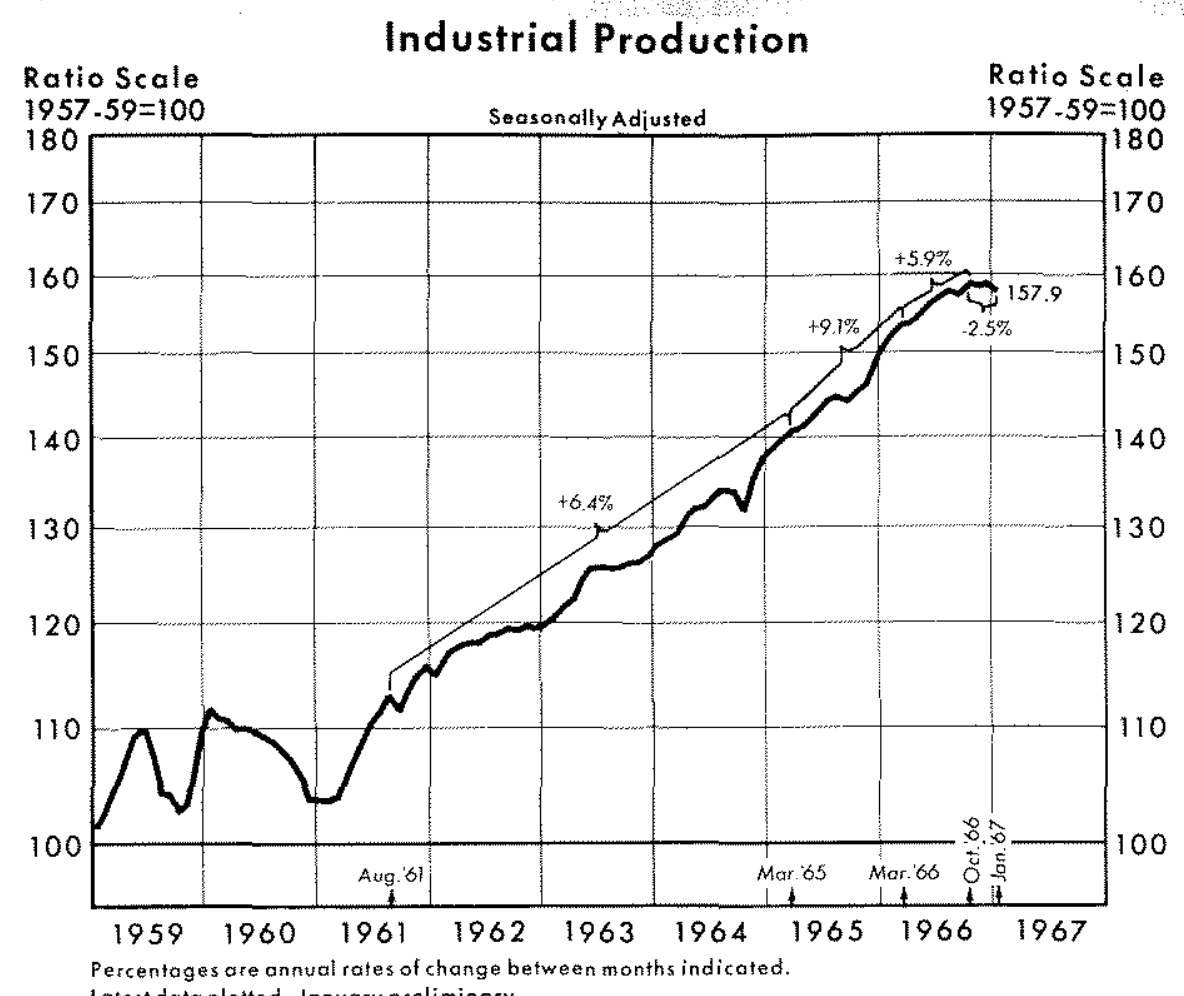

\section{Industrial Production}

feeding on itself. For example, the 1966 decline in new residential construction has been reflected in output declines of the lumber industry and in little change in the rate of furniture and fixtures production. The decline in iron and steel production since August may be associated with the decline in new construction as well as the smaller automobile sales.

Employment, in contrast with most other measures of economic activity, has continued to expand rapidly. From August to January total employment increased at a 3.7 per cent annual rate compared with a rise of 2.7 per cent during the year ending last August. Payroll employment has also continued to rise substantially. From August to January payroll employment increased at a 4.4 per cent annual rate compared with 5.2 per cent in the previous 12 months. These rates of growth may be compared with growth of population of labor force age at a rate of about 1.5 per cent a year.
Unemployment has remained at slightly below 4 per cent of the labor force. The average workweek in manufacturing declined from 41.5 hours last September to 40.9 hours in January.

\section{Frices}

The smaller expansion in total demand has reduced the demand-pull pressures on prices, but cost-push forces may be rising. The strong demand for labor and for goods dur. ing 1966 has not been fully reflected in wages (and some other prices) since many contracts have not come up for renegotiation. Mark-ups in these prices, in turn, increase costs of production and place cost-push pressures on other prices.

Consumer prices increased at about a 1 per cent annual rate from October to January compared with 3.7 per cent during the preceding 12 months. Most of the gain since October has been in the cost of services; the prices of commodities have changed little on balance, with declines in food being nearly matched by mark ups in other nondurable goods.

Wholesale prices have declined since last summer in contrast to the continued rise in consumer prices. From August to January wholesale prices decreased at an annual rate of 1.3 per cent compared with an increase of 3.8 per cent in the preceding year. Farm products and processed foods have contributed most to this recent decline. Prices of these commodities declined abruptly last fall, partially offsetting the 8 per cent rise during the 12 months ending last September. Industrial prices have continued to work up, increasing since September at a 1.7 per cent annual rate compared with a 2.4 per cent increase in the previous year.

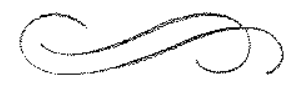

